\title{
Childhood emotional experience within the family relation to the current partnership and the desire to have children
}

\author{
I. Tretjakova ${ }^{1}$ and S. Mihailova ${ }^{2}$ \\ ${ }^{1}$ Daugavpils University, Daugavpils, Latvia \\ ${ }^{2}$ Rīga Stradinsš University, Riga, Latvia
}

\begin{abstract}
The paper studied the relationship between emotional experience in childhood and the quality of the existing partnerships. With a questionnaire, specifically designed by I. Tretjakova, 221 respondents aged 20-40 years were interviewed. The study leads to the conclusion that a positive emotional experience in childhood helps to develop emotionally healthy environment in marriage (including unregistered or civil partnership), and creates the desire to have children, and vice versa, emotionally negative experience in childhood disturbs the creation of an emotionally favourable environment for marriage and causes conflicts in relationships, provokes desire to divorce, but it cannot be stated that more interpersonal problems are the cause of lower birth rates than there are at fewer marital problems. The study confirms that a stable marriage can be an important factor contributing to the woman's desire to have children Thus it can be assumed that development of emotion regulation skills could be a contributing factor in order to form successful partnerships and promote birth of more children in the family context.
\end{abstract}

Key words: Birth-rate, childbirth influencing factors, factors affecting birth-rate, partnership quality, emotional experience in childhood, emotional intelligence

The new socio-economic conditions have had an impact on the emotional atmosphere, quality of relationships in families (Рукова, 1993), and thus - marriage and the desire to have children. A decrease in birth rates has been observed in the last few years. Demographers explain these data with economical downturn, but due to the lowering birth rates mainly in the economically developed countries, it is suggested that the cause of birth rate lowering is not only economical, but also social and psychological (Molnar \& Kapitany, 2002). Along with changes in society, beliefs about duration, value and stability of marriage also shifted (Рукова, 1993).

For the children to develop in a healthy way, contribution of both parents - mother and father - is necessary so that the child could understand the approval and closeness (mutual trust, sharing the most intimate thoughts and feelings, compassion, caring and tenderness) of two opposite sexes. It produces a stable personality in the future that promotes acceptance of sex differences, understanding of having children, and the role and functions of parenting, understanding of the value of the family and inclusion in the family history. If the child is being raised only by the mother, he forms relatively stable understanding about child-single parent relationship model (Besson \& Brault, 1995) thus there is a possibility that in adulthood this person could form "mother/child" relationships instead of male/female ones, which could 
cause emotional and behavioural problems. Negative childhood experience in the family of origin could also be the cause of low birth rates (Goltsova \& Leshchenko, 2011).

It has been found that current partnership quality depends on factors in the past - from the emotional environment during childhood in parents family, parents' ability to tolerate, evaluate and control their emotions (Field, 1988; Neff \& Broady, 2011) and from the present factors - partner's characteristics, emotional intelligence (Neff \& Broady, 2011; Čukurs, 2015; Goulmens, 2001) ability to forgive (McCullough et al., 1997; Fincham, 2000; Hill, 2001; Allemand et al., 2007), to solve problems (Worthington \& DiBlasio, 1990, as mentioned Kachadourian et al., 2004), to communicate (and the quality of intimacy in the relationships). The main aspect of qualitative partnership is spouse's subjective satisfaction with the relationship, with the partner and with marriage in general (Dolto, 1997; Shiota \& Levenson, 2007; Султанова, 2008; Rosowsky et al., 2012). Recent studies (Shiota \& Levenson, 2007; Султанова, 2008; Rosowsky et al., 2012) suggest that emotionally favourable environment for marriage is largely determined by personal characteristics of the spouse - the higher is husband's satisfaction with marriage, the higher it is for his wife and vice versa, the less is the husband satisfied, the less is his wife. In addition, the introverted, neurotic (melancholic) women are more likely to be satisfied with the marriage than women of other temperament (Андреева \& Толстова, 2001). Studies have obtained conflicting data on similarities and differences between registered and unregistered marriages (Лидовская, 2009; Musick \& Bumpass, 2012).

Since no research data was found on the connection between emotional experience in the past and the desire to have children, the goal of this paper was to find out the link between the emotional experience in childhood, quality of the existing relationship and desire to have children.

In order to achieve the aim, the following tasks were brought forward: to determine how emotional experience in the family of origin is connected to emotional quality of the current partnership; to determine how emotional experience in the family of origin is connected with the desire to have children; to determine if marriage is one of the contributing factors to the desire to have children. Several hypotheses were stated: an emotionally healthy experience in childhood helps to form emotionally beneficial environment in marriage (also in unregistered partnership) and created the desire to have children and vice versa - emotionally unhealthy experience in childhood (emotional violence) disrupts the formation of emotionally healthy environment in marriage and decreases the desire to have children; 2- a legal marriage is a contributing factor for women to have children.

\section{Materials and methods}

\section{Research methods}

Pilot study, conducted in 2012-2013 in Latvia, is a part of greater research which aims at identifying causes of the low birth rate risk in Latvia by focusing not only on the financial, but also on the psychological aspects. The current paper analyses only a part of the obtained data on factors promoting birth rate in Latvia and it is a continuation of the paper in the previous issue/volume about the monetary satisfaction and satisfaction with marriage as a birth rate promoting factors in Latvian families.

The study used for research purposes specially designed I.Tretjakova's survey "Survey on factors influencing birth rate in Latvia", which consisted of parts of demographic data and narrative section. The survey questions were designed basing on the analysed studies of low birth rates in Europe and the world. The socio-demographic indicators of the survey provided an opportunity to clarify such indicators as: the individual's gender, age, nationality, 
marital status, living environment, education, working environment, as well as obtained information on the current and planned number of children in the family. The narrative included issues (total of 8 blocks) about the partnership, raising children, personal childhood experience, health and pregnancy, parental relations with children, values, factors which affect the willingness or unwillingness to have children. Overall, the survey consisted of 28 questions and gave the opportunity to obtain both quantitative and qualitative data. However, this study analyzed only a fraction of the issues relating to the research topic of this article, i.e. the question blocks about relations with a partner, about personal childhood experience and the desire to have children.

To test the results of the survey, a structured interview with 4 married couples was conducted, recorded and analysed in 2014.

\section{Implementation of the study process}

This was a pilot study, which took place in electronic questionnaire form from 2012 till 2013 because of the need to get just a glimpse in certain variable links. Participants answered questions in the absence of direct contact with the researchers. Along with the questionnaire in electronic form there was a covering letter sent about the survey objectives and research ethics - guaranteeing anonymity and confidentiality.

In order to assess the obtained results, a semi-structured interview with 4 married couples was carried out. The couples had been married for 10-20 years and had children. Interviews were conducted individually with each spouse, including questions about personal childhood experience, about relationships in marriage and the decision on having children.

\section{Statistical analysis of the data}

All study data were entered into the data analysis statistical program SPSS. Data were summarized mathematically and statistically compared using Pearson correlation analysis, variance analysis, T-criterion analysis.

\section{Characteristics of the research sample}

Overall, the study included 221 respondents: 185 women (mean age -30.6) and 36 men (mean age -32.0$)$ age $20-40(\mathrm{~N}=221)$, of which $59 \%$ had children $(42 \%-1$ child, $40 \%$ 2 children -3 children $18 \%$ ), and $41 \%$ - didn't. Each respondent represented his own family. Of those who live unmarried, $17 \%$ have children, $83 \%$ - do not. Among those who are married $-85 \%$ have and $15 \%$ - do not. Among those who are divorced $-82 \%$ have children, $18 \%$ do not have children.

\section{Results}

To assess the results, statistical analysis was calculated between the different variables.

Figure 1 shows that people who are in marriage, have more children - in $85 \%$ of cases they have children, while those who live in a consensual union $-17 \%$ have no children. It means that marriage could be an important factor associated with the creation of children. Analysis of polarity of childhood experience (see Figure 2) shows that the majority of respondents $(79 \%)$ have negative childhood experience. Only $21 \%$ of respondents note that in their childhood they had only positive experience (possibly a denial of negative experience). 


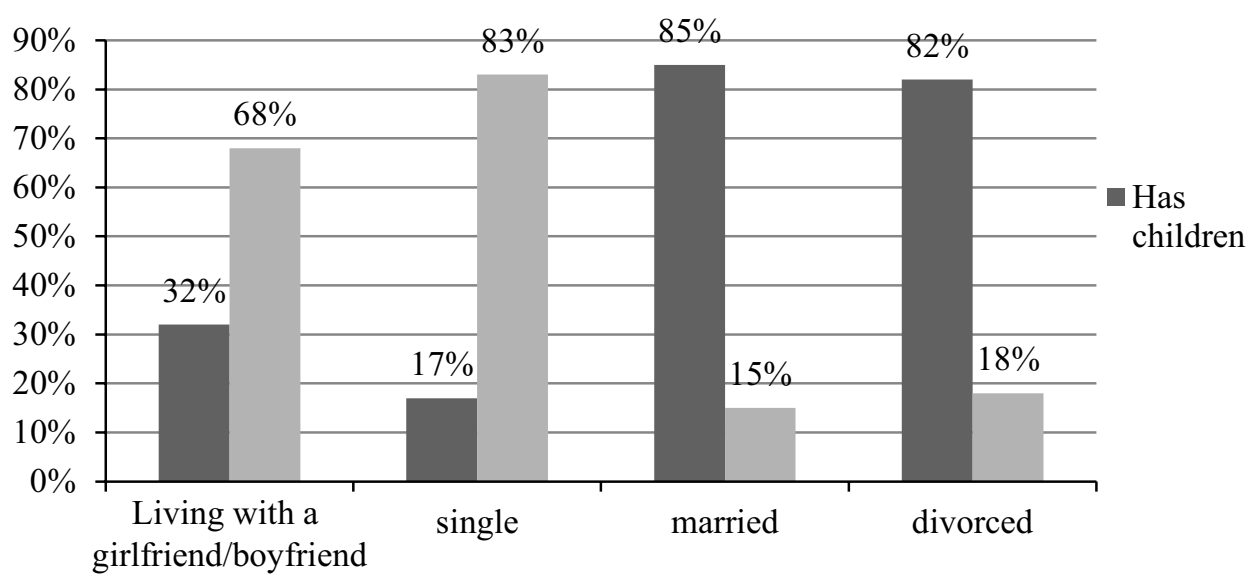

Figure 1. Marital status and number of children frequency distribution $(\mathrm{N}=221)$.

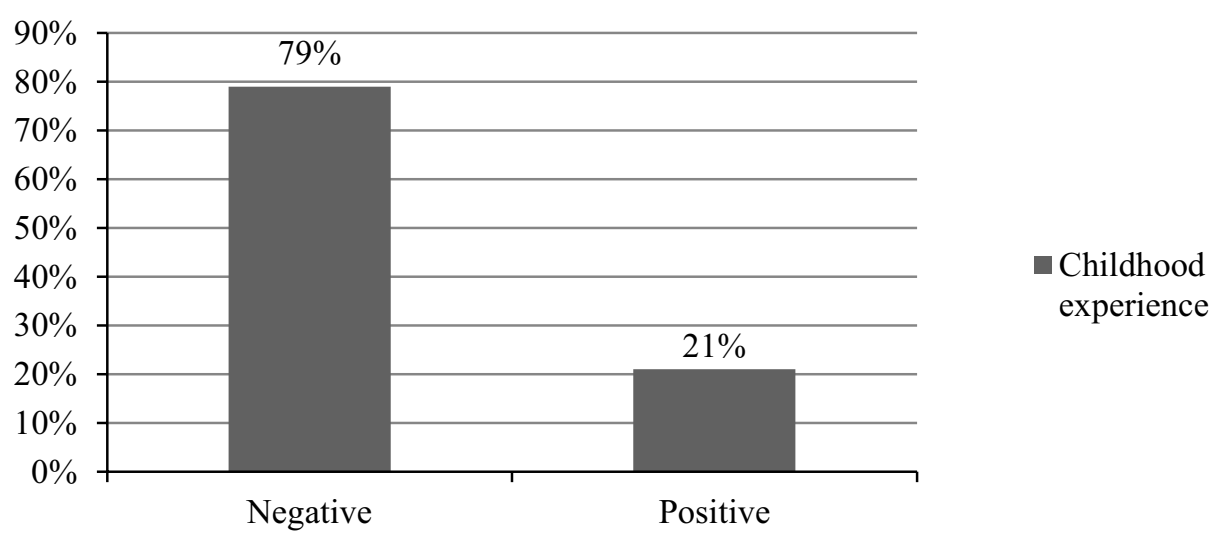

Figure 2. Frequency of positive and negative emotional childhood experience among respondents in the group.

Looking at the six key factors associated with personal negative childhood experiences: parental divorce/ mutual conflicts, lack of parental attention, alcohol abuse, emotional/ physical abuse within the family (see Fig. 2), it was found that for the most part the respondents faced parental conflicts $(53 \%)$, divorce (34\%), and deficits of attention, and alcohol intake (31\%).

To the question - whether personal childhood experiences affect existing relations $67.1 \%$ responded affirmatively, but $17.6 \%$ answered negatively (see Fig. 4).

Thus it can be assumed that, in general, emotional childhood experience may be relevant in the development and quality of the relationships in adulthood.

If we look at how the positive and negative experience affects different relations (see Table 1), we find statistically significant difference only between negative experience in childhood and conflicts in partnership $(\mathrm{F}=3.797$, sig. $=0.051)$. ANOVA analysis shows that there is no statistically significant difference between the group with positive and negative childhood experiences and the group with other statements that describe their current partnership. 


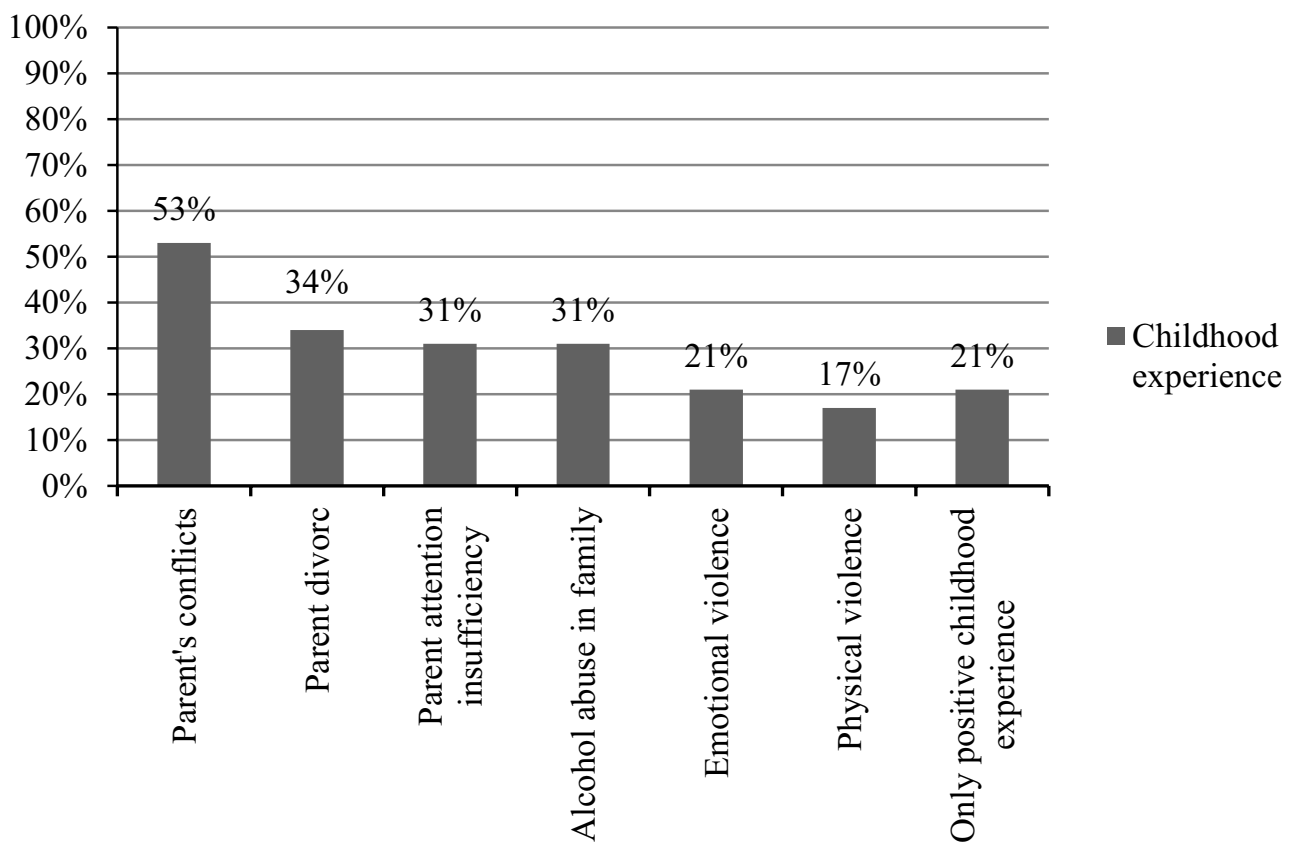

Figure 3. Personal childhood experiences in the family $(\%, \mathrm{~N}=221)$.

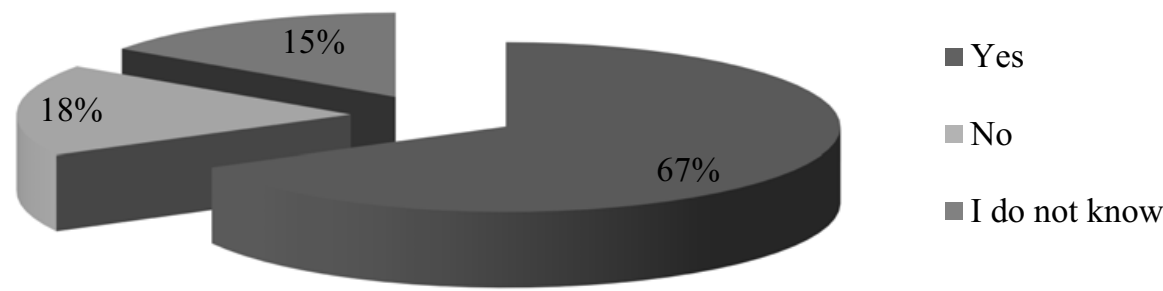

Figure 4. Respondents' opinion on how personal childhood experiences influence the current partnership.

This allows us to conclude that partners with negative childhood experience develop more conflicting relations than those partners that have positive childhood experience. It could not be stated that partners with more positive childhood experience are more satisfied with their current relationship than partners who have negative experience. It also could not be stated that respondents with a positive childhood experience feel more secure, emotionally comfortable, more respected, trust, are able to discuss everyday issues in a calm manner and share their experience more than partners who have negative childhood experience.

In order to determine the quality of relationships between partners, the survey included five relationship problems: emotional/physical violence, alcohol/drug abuse and computer addiction (see Table 2).

Table 2 shows that in the respondents' families the most common type of relationship problems are emotional violence, and other most commonly mentioned problems are computer addiction and alcohol abuse. 
Table 1. Questions characterising marital satisfaction and childhood emotional experience.

\begin{tabular}{|l|c|c|c|}
\hline $\begin{array}{l}\text { Questions characterising } \\
\text { marital satisfaction }\end{array}$ & $\begin{array}{c}\text { Some negative } \\
\text { childhood } \\
\text { emotional } \\
\text { experience }\end{array}$ & $\begin{array}{c}\text { Only positive } \\
\text { childhood } \\
\text { emotional } \\
\text { experience }\end{array}$ & Significance \\
\hline $\begin{array}{l}\text { Feeling safe in relationship } \\
\text { with the partner }\end{array}$ & 3.18 & 3.17 & .987 \\
\hline Can trust the partner & 3.34 & 3.37 & .846 \\
\hline Mutual respect & 3.34 & 3.30 & .761 \\
\hline $\begin{array}{l}\text { Share emotional experience, } \\
\text { thoughts, opinions, joys }\end{array}$ & 3.21 & 3.17 & .793 \\
\hline $\begin{array}{l}\text { Are able to calmly discuss } \\
\text { cohabitation issues }\end{array}$ & 2.93 & 3.00 & .652 \\
\hline Relationship is characterised by conflicts & $\mathbf{1 . 4 5}$ & $\mathbf{1 . 2 1}$ & $\mathbf{. 0 5 1}$ \\
\hline $\begin{array}{l}\text { Feels emotional comfort } \\
\text { in relationship }\end{array}$ & 2.80 & 2.89 & .572 \\
\hline $\begin{array}{l}\text { Feels emotional isolation and } \\
\text { loneliness in relationship }\end{array}$ & 1.07 & .95 & .453 \\
\hline Satisfied with relationship & 2.99 & 2.98 & .988 \\
\hline
\end{tabular}

Table 2. Relationship problems and their frequency in families (\%).

\begin{tabular}{|l|l|c|c|c|c|}
\hline $\begin{array}{l}\text { Problems in our } \\
\text { relationships are created by: }\end{array}$ & $\begin{array}{l}\text { All the } \\
\text { time }\end{array}$ & Often & Sometimes & Seldom & Never \\
\hline Emotional violence & $1.4 \%$ & $5.4 \%$ & $16.7 \%$ & $22.5 \%$ & $54.1 \%$ \\
\hline Physical violence & & $0.5 \%$ & $1.4 \%$ & $5.0 \%$ & $93.2 \%$ \\
\hline Alcohol addiction & $1.4 \%$ & $4.1 \%$ & $5.9 \%$ & $15.8 \%$ & $72.9 \%$ \\
\hline Drug addiction & & $0.9 \%$ & $0.5 \%$ & $2.7 \%$ & $95.9 \%$ \\
\hline Computer addiction & $1.8 \%$ & $5.0 \%$ & $14.1 \%$ & $23.6 \%$ & $55.5 \%$ \\
\hline
\end{tabular}

Looking at the connection between the relationship problems and child birth ratio, drug use is statistically significantly associated with number of children in the family, this relationship is weak and negative $(\mathrm{r}=-0.16 ; \mathrm{p}=0.025)$. Any other partnership problem does not show statistically significant relationship with the child birth. Thus, it cannot be argued that the mutual relationship problems are associated with child birth.

\section{The obtained results of interviews}

To verify the results obtained in the survey, a structured interview was carried out with 4 couples whose marriage duration is 10-20 years and who have children. Two of the married couples felt that their parents' families had been emotionally favourable and 2 of the married couples felt that their parents' families have been emotionally negative. The interview was conducted individually with each of the spouses. Interview questions included questions about personal childhood experience, about relations in marriage, and about the choice to have children. All couples stated that their childhood experiences had affected their marriage, especially in the beginning. The problem-solving model of parent families was automatically transferred to the marriage. Only when this model was brought into awareness, they managed consciously not to repeat the parents' behaviour.

Parent family experience affected the values and rules of marriage, behaviour models and expectations from the other partner. Problems started if, in the beginning, the partner did not act as the other expected them to. It took a while to accept that the partner could act differently from the behaviour adopted in the parent family. 
All couples stated that their well-disposed emotional experience in childhood in parent family helped to build an emotionally beneficial environment for marriage, that the problem solving models adapted from parents were useful in the conflict resolution in their marriage.

However couples with emotionally negative experience in parent families stated that negative emotional experience and emotional violence in childhood constrains the development of an emotionally favourable environment for marriage and contributed to the divorce. Only family therapy was beneficial to achieve saving marriage rather than divorcing.

Thus, the interviews show the relationship between childhood experience and current difficulties in partnership. Respondents, who point to the emotionally favourable environment in childhood in parent family, are the same who have positive marriage experience rather than those who were in an emotionally hostile environment.

Asking about the issue of how marriage effects decision to have children, all the wives acknowledged that the status "married woman" instantly gives greater security for the future and with it the desire to have children. As for the husbands, the marriage factor has not been an important factor to approve his wife's desire for a child. Therefore it can be stated that a stable marriage for a woman is an important factor to cause the desire to have children.

\section{Discussion}

Analysis of the results gives evidence that childhood experience in parent family is essential to adult's ability to resolve conflicts in partnership. If the parents are unable to identify, assess and control their emotions, the child's ability to develop skills for emotional communication is disturbed - the development of child's emotion regulation is delayed, which can cause behavioural problems in the future. Goleman stresses that emotional communication skills are not innate, but are acquired during lifetime and they can be learnt in a better or worse matter, much like reading. (Goleman, 2001).

The survey showed that the majority of respondents had had negative childhood experiences, and most of the participants mentioned that their childhood experiences affect their current partnership.

The birth of children - a mature choice to have children, to take responsibility for their upbringing is associated with internally arranged human - male and female - emotional stability, which contributes to the ability to build a mutual partnership and creates a stable, sustainable environment in which children can be born.

In comparison with other authors' studies of the factors affecting birth rate (Berga et al., 2005; Zamotkina \& Žarkovs, 2011) it could be concluded that our research results virtually confirm such aspects as emotional well-being in the relationships, which is described in papers (Goltsova \& Leshchenko, 2011; Neff \& Broady, 2011), stressing the importance of promoting birth rates.

Continuing the discussion on the importance of emotions in a partnership, it is an important descriptor of successful marriage and family relationships. The study shows that marriage is one of the contributing factors to the choice to have children, which in turn corresponds to Vinokor-Kaplan conclusion that marriage and its duration has an impact on child birth ratio (Vinokor-Kaplan, 1973). If the partners' relationships are officially registered, then children are born in an orderly, safe environment, where the parents take responsibility for each other and therefore for raising children.

In Latvia it would be necessary to begin to realize psychological problems that affect low birth rate. Studying the reasons of low birth rate it is important to pay attention to the 
emotional quality of the partnership, which is significantly affected by partners' emotional intelligence - understanding and management of emotions, which is a crucial for a successful social interaction. In order to have healthy children, the environment in the family must be positive, which gives the child emotional security and sense that the child is wanted, loved, accepted and highly regarded. Such environment creates a safe and strong basis for the child later in life. When a child becomes an adult himself, this childhood experience will help him to enter the adult world and to build a healthy partnership with the opposite sex and to have children, in order to continue family/humanity.

\section{Conclusions}

- Emotional childhood experience could be related to the relationship development and quality in adulthood, especially to the skills to build mutual partnership without sharp conflicts.

- Partners with negative childhood experiences have more conflicting relationships than those that have positive childhood experience, but it cannot be stated that partners with more positive childhood experience are now more satisfied with their relationship than couples with negative experiences and that their relationships have less deviant tendencies than partners with negative experiences

- Positive emotional experience in childhood helps to create an emotionally favourable environment in marriage (including unregistered or consensual partnership) because the learned parental problem solving models are useful for their marital conflict resolution and create a desire to have children, and vice versa, an emotionally negative experience in childhood disturbs building of an emotionally supportive environment in marriage, makes the relationships more conflicting, provokes the desire to divorce, but it cannot be stated that interpersonal problems cause lower birth rates more than if there are less problems.

- The study confirms that a stable marriage could be an important factor in relation to the woman's choice to have children

- Thus, it can be assumed that skills of emotion regulation, especially development of skills for constructive disagreement solving and contradiction could be a contributing factor for successful partnership formation and increase in births rates in the family context.

The birth of children is associated with the ability of both genders to live in relationship, a healthy morally-psychological climate in mutual relationship and with satisfaction with marriage. Male and female ability to build a harmonious relationship is a model of healthy gender socialization that promotes the child's mental, physical and social health. In order to raise the birth rate in the country, it is important to take into account the correlation; there must be a common approach and policy in order to achieve long term positive results.

Research limitations: a small number of respondents, males and females are not analyzed separately, the analysis does not take into account the duration of the couple's relationship, because couples in the relationship are subjected to certain cycles and depending on the phase in which they currently are in, the evaluations of their current emotional environment may vary. The study examined only the traditional union (male-female) relationship. This sample did not include disadvantaged families, families at social risk and families without income, living solely on benefits, so the deviance trends families were small.

This study addressed the issues that require in-depth research. The results do not describe the whole situation in Latvia, because the sample was rather small and the results cannot be extended to the whole general sample. Since this was a pilot study, the causalities cannot be 
established, only trends. The research task in the future is to determine whether the results could be confirmed in a larger study group.

\section{References}

[1] Allemand, M., Amberg, I., Zimprich, D., Fincham, F. D. (2007). The role of trait forgiveness and relationship satisfaction in episodic forgiveness. Journal of Social and Clinical Psychology, 26: 199-217.

[2] Berga, G., Tiltiņa, I., Buša, I., Dūšelis, S., (2005) Laulību šķiršanas, laulību noturības un dzimstības veicinošo faktoru izpēte http://www.lm.gov.lv/upload/berns_ gimene/bernu_tiesibas/petijums_lauiliba.pdf

[3] Besson J., Brault Y. (1995) Les trois formes. Manuel d'enseignement de l'EFAPO, tome 4, 1995.

[4] Čukurs, E., (2015) Intelekts. Grām: Psiholoǵija 1: Pamatjautājumi - teorijas un pétījumi. (K.Martinsones, A.Miltuzes red.) R: Zvaigzne ABC, 216-236.

[5] Dolto F. (1997) Viss ir valoda. R: Preses nams.

[6] Dūšelis, S. (2007). Partnerattiecību kvalitātes un intimitātes pakāpes saistība ar kopdzīves rūpju sfērām https://dspace.lu.lv/dspace/handle/7/10697? locale-attribute $=$ de

[7] Field, D. (1988). Family Personalities. Harvest Heuse.

[8] Fincham, F. D. (2000). The kiss of porcupines: From attributing responsibility for forgiving. Personal Relationships, 7, 1-23.

[9] Goltsova, E., Leshchenko, 1. (2011), Factors of the Social Environment as Determinants of Marriage and Birthrates. Sociological Research, 50(6), $51-60$.

[10] Goulmens, D. (2001). Tava emocionālā inteliǵence. Rīga: Jumava.

[11] Hill, E.W. (2001). Understanding Forgiveness as Discovery: Implications for Marital and Family Therapy. Contemporary Family Therapy, 23, 369-384.

[12] Kachadourian, L.K., Fincham, F., Davila, J. (2004). The tendency to forgive in dating and married couples: The role of attachment and relationship satisfaction. Personal Relationships, 11, 373-393.

[13] McCullough, M. E., \& Worthington, E. L., Rachal, K. C. (1997). Interpersonal forgiving in close relationships. Journal of Personality and Social Psychology, 73, 321-336.

[14] Molnar S., Kapitany B. (2002). Gyermekcentrikus érzelmek és egyéni célok, vágyak viszonya. Századvég, 25, 97-116.

[15] Musick, K., Bumpass, L., (2012), Reexamining the Case for Marriage: Union Formation and Changes in Well-being. Journal of Marriage and Family 74.1: $1-18$.

[16] Neff, L. A., Broady, E. F. (2011), Stress resilience in early marriage: can practice make perfect? USA: Journal of Personality and Social Psychology. 101(5), 1050-1067.

[17] Rosowsky, E., King, K., Coolidge, F., Rhoades, C., Segal, D. (2012), Marital Satisfaction and Personality Traits in Long-Term Marriages: An Exploration Study. Clinical Gerontologist, 35 (2), 77-78.

[18] Shiota, M., Levenson, R. (2007), Birds of a Feather Don't Always Fly Farthest: Similarity in Big Five Personality Predicts More Negative Marital Satisfaction Trajectories in Long-Term Marriages. Psychology and Aging, 22(4), 666-675. 
[19] Vinikor-Kaplan, D. (1973) Trends and Changes in Family Structure and Planning. Society and Welfare, 2: 51-63.

[20] Zamotkina, J., Žarkovs, V. (2011) Faktori, kas ietekmē dzimstību Latvijā, Eiropā un pasaulē.

[21] Андреева, Т. В., Толстова, А. В. (2001) Темперамент супугов и совместимость в браке. Ананьевские чтения: Тезисы научнопрактической конференщии. СПб.

[22] Лидовская, Н. (2009) Взаимоотношения супугов в незарегистрированном брак. Диссертацияю СПб. http://www.dissercat. com/content/vzaimootnosheniya-suprugov-v-nezaregistrirovannombrake\#ixzz3d48DiUW4

[23] Рукова, Е. (1993) Социально-демографические аспекты устойчивости брака. Диссертации. Москва: BAK http://economylib.com/sotsialno-demograficheskie-aspekty-ustoychivosti-braka \#ixzz3d4XDXTZN

[24] Султанова, А. (2008). Социально-психологические особенности супружеской совместимости и благополучия в брачных отношениях: диссертация. СПб. 